\title{
Electrochemical and theoretical study on the role of thiosemicarbazide derivatives as corrosion inhibitors for $\mathbf{C}$-steel in $\mathrm{HCl}$ solution
}

\section{Ahmed M. Eldesoky*1, Hala.M.Hassan ${ }^{2}$, Ismat H. Ali ${ }^{3}$, Musa E. Mohamed ${ }^{4,5}$ and Samir Bondock $^{3,6}$}

1Engineering Chemistry Department, High Institute of Engineering \& Technology (New

Damietta), Egypt and Al-Qunfudah Center for Scientific Research (QCSR), Al-Qunfudah

University College, Umm Al-Qura University, KSA. a.m.eldesoky79@ hotmail.com

2Textile Technology Department, Industrial Education College, Beni-Suef University, Egypt

and Chemistry Department, Faculty of Science, Jazan University, KSA.

dr.halamahfooz@yahoo.com

3Chemistry Department, Faculty of Science, King Khalid University, 9004Abha, Saudi

Arabia.ismathassan@gmail.com

4Chemistry Department, College of Science, Al-Baha University, Al-Baha, Saudi Arabia.

5Department of Chemistry, College of Applied and Industrial Sciences, Bahri University,

Khartoum, Sudan. a.m.eldesoky79@gmail.com

6Chemistry Department, Faculty of Science, Mansoura University, 35516 Mansoura, Egypt.

bondock@mans.edu.eg

\section{ABSTRACT}

The efficiency of two thiosemicarbazide derivatives; 4-phenyl-thiosemicarbazide and 4allyl-thiosemicarbazide as corrosion inhibitors against $\mathrm{C}$-steel and its adsorption behavior were investigated in $2 \mathrm{M} \mathrm{HCl}$ solution using potentiodynamic polarization, electrochemical impedance spectroscopy (EIS) and electrochemical frequency modulation (EFM) techniques. Results revealed that the inhibition efficiency increased with the inhibitor concentration and also indicate both thiosemicarbazide derivatives act as mixed-type inhibitors. EIS spectra exhibit one capacitive loop and confirm the inhibitive ability. Quantum chemical calculations have been employed for the inhibition efficiency of these thiosemicarbazide derivatives for Csteel in aggressive acidic media by means of density functional theory (DFT) methods B3LYP/6-31 $\mathrm{g}^{*}$ in gas phase. The calculated quantum chemical parameters correlated to the inhibition efficiency are, $\mathrm{E}_{\mathrm{HOMO}}, \mathrm{E}_{\mathrm{LUMO}}$, energy of the gap $(\Delta \mathrm{E})$, charge on the reactive center, dipole moments and global hardness. Both experimental and theoretical investigations prove that 4-phenyl-thiosemicarbazide can inhibit better than 4-allyl-thiosemicarbazide. SEM and EDX examination of the $\mathrm{C}$-steel in $2 \mathrm{M} \mathrm{HCl}$ surface revealed that these compounds prevented C-steel in $2 \mathrm{M} \mathrm{HCl}$ from corrosion by adsorption on its surface to form a protective film and acts as a barrier to corrosive media. Molecular docking was utilized to predict the binding among thiosemicarbazide derivatives with the receipt of breast cancer mutant $3 \mathrm{tt} 8$.

Key words: Thiosemicarbazides, C-steel, DFT, SEM-EDX, Molecular docking.

Corresponding Author: Ahmed M. Eldesoky 


\section{INTRODUCTION}

There are many uses of acids in industrial sector such as oil well acidification, cleaning and pickling of metals and alloys and ore production [1-3]. For this reason, there is an increase demand for new techniques to control and suppress corrosion which induced by using of acids. Among these techniques, chemical inhibitors have been adopted as a cost-effective manner for inhibiting acid corrosion [4-9]. Various organic compounds, such as acetylenic alcohol, quaternary ammonium salts and compounds containing hetero atoms are extensively used as corrosion inhibitors in several industries. The organic molecules are adsorbed on the surface of the metal or alloy via the hetero atom e.g. such as $\mathrm{O}, \mathrm{S}$ and $\mathrm{N}$, blocking the active sites and creating a thin film to diminish the passage of corrosive sorts to the metal/alloys surface [10-16]. There are many factors affecting adsorption of molecules on the surface of metals or alloys (i) nature of surface (ii) charge of the metal (iii) chemical structure of inhibitors. Among organic compounds, heterocyclic molecules having nitrogen atoms, such as pyrazolone compounds proved to have effective corrosion inhibition properties, lack of irritating odor and excellent thermal stability for a lot of metals and alloys in several corrosive media [17-22]. Experimental techniques are suitable in elucidation the mechanism of inhibition but they are often consuming and expensive. Rapid development in theoretical chemistry and computer software and hardware provides very effective computing and graphical tools for researchers. Recently, there are many corrosion studies containing significant quantum chemical calculations have been performed [23-26]. Such calculations are typically used to investigate the electronic properties of corrosion inhibitors, the effect of the highest occupied molecular orbital (HOMO), the lowest unoccupied molecular orbital (LUMO) energies, the difference between them $\left(\mathrm{E}_{\mathrm{LUMO}}-\mathrm{E}_{\mathrm{HOMO}}\right)$, global hardness, dipole moments, charge on the reactive center and total energies in order to achieve the appropriate correlation [27, 28]. Theoretical studies on inhibition action of some thiosemicarbazones and amides have been reported recently [29].

In this study the density function theory (DFT) is used to investigate the structural properties of two thiosemicarbazide derivatives in aqueous phase in order to understand their inhibition mechanism. Another purpose of the present study is to discuss the corrosion inhibition of $\mathrm{C}$-steel in acidic medium using the two thiosemicarbazide derivatives and to propose a suitable mechanism for the inhibition using the potentiodynamic polarization curves, electrochemical impedance spectroscopy (EIS) and electrochemical frequency modulation (EFM) methods. SEM and EDX examination of the C-steel in $2 \mathrm{M} \mathrm{HCl}$ surface revealed that these compounds prevented $\mathrm{C}$-steel in $2 \mathrm{M} \mathrm{HCl}$ from corrosion by adsorption on its surface to form a protective film and acts as a barrier to corrosive media. Molecular docking was utilized to predict the binding among thiosemicarbazide derivatives with the receipt of breast cancer mutant $3 \mathrm{tt} 8$.

\section{EXPERIMENTAL METHODS}

\subsection{Materials and Methods}

C-steel was used for all corrosion measurements. Its composition (wt \%) is $0.20 \mathrm{C}, 0.045$ $\mathrm{P}, 0.30 \mathrm{Si}, 0.53 \mathrm{Mn}, 0.055 \mathrm{~S}, \mathrm{Fe}$ balance. The aggressive solution $(2 \mathrm{M} \mathrm{HCl})$ was prepared by dilution of $\mathrm{HCl}$ (analytical grade, 37\%) with bi-distilled water. The chemical structures of the thiosemicarbazide derivatives used in this study are shown in Table 1 [30]. 
Table 1: Molecular structures, names, molecular weights and molecular formulas of investigated compounds.

\begin{tabular}{|c|c|c|c|}
\hline $\begin{array}{c}\text { Compound } \\
\text { No. }\end{array}$ & Structure & $\begin{array}{c}\text { Mol. Wt. / Mol. } \\
\text { Formula }\end{array}$ \\
\hline 1 & & $\begin{array}{c}\text { 4-phenyl- } \\
\text { thiosemicarbazide }\end{array}$ & $167.23 / \mathrm{C}_{7} \mathrm{H}_{9} \mathrm{~N}_{3} \mathrm{~S}$ \\
\hline 2 & & & 4-allyl- \\
thiosemicarbazide & $131.20 / \mathrm{C}_{4} \mathrm{H}_{9} \mathrm{~N}_{3} \mathrm{~S}$ \\
\hline
\end{tabular}

\subsection{Preparation of compounds}

Both 4-allylthiosemicarbazide and 4-phenylthiosemicarbazide were prepared by the respective addition of equimolar quantities of allyl isothiocyanate and phenyl isothiocyanate to a cold solution of hydrazine hydrate $(99 \%)$ in absolute ethanol following the literature procedure [31].

\subsection{Electrochemical measurements}

Electrochemical measurements were carried out in a three electrodes thermostated cell assembly using a Gamry potentiostat/galvanostat/ZRA (model PCI300/4). A saturated calomel electrode (SCE) and platinum were used as reference and counter electrodes, respectively. The $\mathrm{C}$-steel electrodes were $1 \times 1 \mathrm{~cm}$ and were welded from one side to a copper wire used for electrical connection. The electrodes were abraded with different grades of emery paper, degreased with acetone, rinsed with bi-distilled water and dried between filter papers. All experiments were performed at $25 \pm 0.1{ }^{\mathrm{O}} \mathrm{C}$. The potentiodynamic curves were recorded from -500 to $+500 \mathrm{mV}$ at a scan rate $1 \mathrm{mV} \mathrm{S}^{-1}$ after the steady state is reached (30 $\mathrm{min}$ ) and the open circuit potential (OCP) was noted after immersion the electrode for 20 min in the test solution.

Electrochemical impedance spectroscopy (EIS) and electrochemical frequency modulation (EFM) tests were conducted using the same instrument as before with a Gamry framework system based on ESA400. Gamry applications include software EIS300 for EIS measurements and EFM140 for EFM measurements; computer was used for collecting data. $E_{\text {chem }}$ Analyst 5.5 Software was used for plotting and fitting data. EIS measurements were carried out in a frequency range of $100 \mathrm{kHz}$ to $10 \mathrm{mHz}$ with amplitude of $5 \mathrm{mV}$ peak-to-peak using ac signals at respective corrosion potential. EFM performed using two frequencies 2 and $5 \mathrm{~Hz}$. The base frequency was $1 \mathrm{~Hz}$. In this study, a perturbation signal with amplitude of $10 \mathrm{mV}$ for both perturbation frequencies of 2 and $5 \mathrm{~Hz}$ was used.

\subsection{Computational details}

The theoretical calculations were carried out by using Density Functional Theory (DFT) method in Gaussian 09 Quantum Chemistry Program, implemented on an Intel Pentum (R) $1.86 \mathrm{~GB}$ personal computer. Initial estimates for the geometries of all the structures were obtained by molecular mechanics program (ACD11) for Widows, followed by full optimization of all geometrical variables (bond lengths, bond angles and dihedral angles), without any symmetry constraint, using Density Functional Theory (DFT) methods in gas 
phase to estimate the quantum chemical parameters. Calculations at DFT level were performed with basic sets $6-31 \mathrm{G}^{*}$.

\subsection{SEM-EDX tests}

The surface of $\mathrm{C}$-steel was obtained by keeping the coins for 3 days putted in $2 \mathrm{M} \mathrm{HCl}$ with and lack of perfect concentration of thiosemicarbazide derivatives, after abraded mechanically utilized unlike papers emery up to grit size 1200 . Then, after this time immersion, the samples were lotion gently with distilled water, carefully dried and mounted into the spectrometer attendance of further treatment. The surface of C-steel was tested utilized an X-ray diffractometer Philips (pw-1390) with Cu-tube $\left(\mathrm{CuK}_{\alpha}, 1=1.54051 \AA\right.$ ), (SEM, JOEL, JSM-T20, Japan).

\subsection{Molecular docking}

This research mimics the real docking labor in which the ligand-protein pair-wise reaction energies are measured utilized Server Docking [32]. The MMFF94 Force field was utilized for energy reduction of ligand molecule utilized Server Docking. Gasteiger partial charges were append to the ligand atoms. Hydrogen atoms non-polar were combined, and rotatable bonds were found. Docking measurements were done on thiosemicarbazide derivatives protein specimen. Mainly hydrogen atoms, Kollman united atom kind charges, and parameters solvation was appended with the aid of tools AutoDock [33]. Attract (grid) maps of $20 \times 20 \times 20 \AA$ grid points and $0.375 \AA$ areas were obtained by utilized the program Autogrid [34]. Distance-dependent dielectric functions and AutoDock parameter set- were utilized in the measurement of the electrostatic terms and van der Waals.

\section{RESULTS AND DISCUSSION}

\subsection{Potentiodynamic polarization measurements}

Measurements of polarization curves were conducted to study the kinetics of the cathodic and anodic reactions. Figure 1 shows the polarization behavior of C-steel electrode in $2 \mathrm{M} \mathrm{HCl}$ in the absence and presence of various concentrations of compound (1). Analogous curve for the other compound has been found (not shown). It is obvious from Figure 1 that both anodic and cathodic reactions are influenced by the inhibitors. It also clear that the inhibition efficiency increases as the inhibitor concentration increases, but the cathodic reaction is more inhibited, meaning that the addition of thiosemicarbazide derivatives reduces the anodic dissolution of $\mathrm{C}$-steel and also hinders the cathodic reactions. Therefore, the investigated thiosemicarbazide derivatives can be classified as mixed type inhibitors.

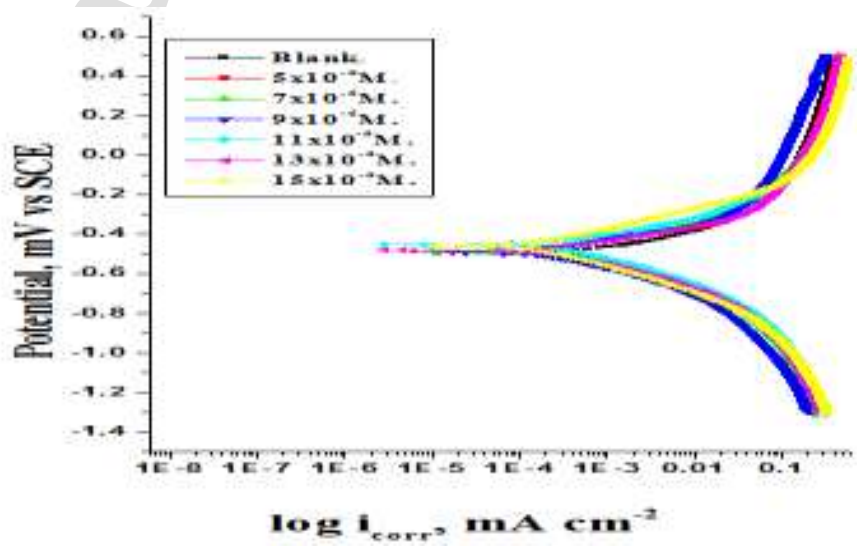

Fig 1: Potentiodynamic polarization curves for the corrosion of $\mathrm{C}$-steel in $2 \mathrm{M} \mathrm{HCl}$ in the absence and presence of various concentrations of compound (1) at $25 \pm 0.1{ }^{\mathrm{O}} \mathrm{C}$. 
The values of electrochemical factors such as corrosion current densities $\left(i_{\text {corr }}\right)$, corrosion potential $\left(\mathrm{E}_{\mathrm{corr}}\right)$, the cathodic Tafel slope $\left(\beta_{\mathrm{c}}\right)$, anodic Tafel slope $\left(\beta_{\mathrm{a}}\right)$ and inhibition efficiency (\% IE) were calculated from the curves of Figure 1 and are listed in Table 2 . The results in Table 2 revealed that the corrosion current density decreases obviously after the addition of inhibitors in $2 \mathrm{M} \mathrm{HCl}$ and \% IE increases with increasing the inhibitor concentration. In the presence of inhibitors $\mathrm{E}_{\text {corr }}$ was enhanced with no definite trend, indicating that these compounds act as mixed-type inhibitors in $2 \mathrm{M} \mathrm{HCl}$. The inhibition efficiency was calculated using Eq. (1):

$\left.\% \mathrm{IE}_{\mathrm{p}}=\left(\mathrm{i}_{\text {corr }}^{\mathrm{o}}-\mathrm{i}_{\text {corr }}\right) / \mathrm{i}_{\text {corr }}^{\mathrm{o}}\right] \times 100$

Where $\mathrm{i}^{\mathrm{o}}$ corr and $\mathrm{i}_{\text {corr }}$ are the uninhibited and inhibited corrosion current densities, respectively.

It is obvious from Table 2 that the slopes of the anodic $\left(\beta_{\mathrm{a}}\right)$ and cathodic $\left(\beta_{\mathrm{c}}\right)$ Tafel lines remain almost unchanged upon addition of organic derivatives, giving rise to a nearly parallel set of anodic lines, and almost parallel cathodic plots results too. Thus, the adsorbed inhibitors act by simple blocking of the active sites for both anodic and cathodic processes. In other words, the adsorbed inhibitors decrease the surface area for corrosion without affecting the corrosion mechanism of $\mathrm{C}$-steel in $2 \mathrm{M} \mathrm{HCl}$ solution, and only causes inactivation of a part of the surface with respect to the corrosive medium $[35,36]$. The inhibition efficiency of these compounds follows the sequence: 4-phenyl-thiosemicarbazide > 4-allylthiosemicarbazide. This sequence may attribute to free electron pair in nitrogen atom, $\pi$ electrons on aromatic nuclei and the substituent in the molecular structure of the inhibitor.

Table 2. Effect of concentrations of the investigated thiosemicarbazides derivatives on the free corrosion potential $\left(\mathrm{E}_{\text {corr. }}\right)$, corrosion current density $\left(\mathrm{i}_{\text {corr. }}\right)$, Tafel slopes $\left(\beta_{\mathrm{a}} \&\right.$ $\beta_{c}$ ), degree of surface coverage $(\theta)$ and inhibition efficiency (\% IE) for C-steel in $2 \mathrm{M} \mathrm{HCl}$ at $25 \pm 0.1^{\circ} \mathrm{C}$.

\begin{tabular}{|c|c|c|c|c|c|c|c|}
\hline Compound & $\begin{array}{c}\text { Conc. } \\
(\mathrm{M})\end{array}$ & $\begin{array}{c}-\mathrm{E}_{\text {corr }} \\
(\mathrm{mV} \text { vs. SCE })\end{array}$ & $\begin{array}{c}\mathrm{i}_{\text {corr }} \\
(\mu \mathrm{A} \mathrm{cm})\end{array}$ & $\begin{array}{c}\beta_{\mathrm{a}} \\
\left(\mathrm{mV} \mathrm{dec}^{-1}\right)\end{array}$ & $\begin{array}{c}\beta_{\mathrm{c}} \\
\left(\mathrm{mV} \mathrm{dec}^{-1}\right)\end{array}$ & $\theta$ & $\%_{\mathrm{IE}}$ \\
\hline \multirow{5}{*}{1} & Blank & 436 & 2.27 & 51 & 124 & ---- & ---- \\
\hline & $5 \times 10^{-6}$ & 485 & 1.28 & 79 & 126 & 0.4361 & 43.61 \\
\cline { 2 - 8 } & $7 \times 10^{-6}$ & 464 & 1.25 & 60 & 131 & 0.4493 & 44.93 \\
\cline { 2 - 8 } & $9 \times 10^{-6}$ & 493 & 1.21 & 106 & 157 & 0.4469 & 46.69 \\
\cline { 2 - 8 } & $11 \times 10^{-6}$ & 471 & 1.14 & 87 & 163 & 0.4977 & 49.77 \\
\cline { 2 - 8 } & $13 \times 10^{-6}$ & 499 & 1.09 & 102 & 155 & 0.5198 & 51.98 \\
\cline { 2 - 8 } & $15 \times 10^{-6}$ & 487 & 1.01 & 113 & 152 & 0.5550 & 55.50 \\
\hline \multirow{5}{*}{2} & $5 \times 10^{-6}$ & 467 & 1.52 & 127 & 182 & 0.3303 & 33.03 \\
\cline { 2 - 8 } & $7 \times 10^{-6}$ & 479 & 1.48 & 88 & 127 & 0.3480 & 34.80 \\
\cline { 2 - 8 } & $9 \times 10^{-6}$ & 456 & 1.45 & 86 & 136 & 0.3612 & 36.12 \\
\cline { 2 - 8 } & $11 \times 10^{-6}$ & 437 & 1.40 & 87 & 125 & 0.3832 & 38.32 \\
\cline { 2 - 8 } & $13 \times 10^{-6}$ & 467 & 1.38 & 64 & 140 & 0.3920 & 39.20 \\
\cline { 2 - 8 } & $15 \times 10^{-6}$ & 488 & 1.28 & 94 & 24 & 0.4361 & 43.61 \\
\hline
\end{tabular}




\subsection{Electrochemical impedance spectroscopy (EIS)}

EIS is well-established and powerful technique in the study of corrosion. Surface properties, electrode kinetics and mechanistic information can be obtained from impedance diagrams [37-41]. Figure 2 shows Nyquist (a) and Bode (b) plots obtained at open-circuit potential both in the absence and presence of increasing concentrations of investigated compound (1) at $25 \pm 0.1{ }^{\circ} \mathrm{C}$. Similar curve for other compound was obtained and is not shown. The increase in the size of the capacitive loop with the addition of thiosemicarbazide derivatives shows that a barrier gradually forms on the $\mathrm{C}$-steel surface. The increase in the capacitive loop size Figure 2(a) enhances, at a fixed inhibitor concentration, following the order: 4-phenyl-thiosemicarbazide > 4-allyl-thiosemicarbazide, confirming the highest inhibitive influence of 4-phenyl-thiosemicarbazide.
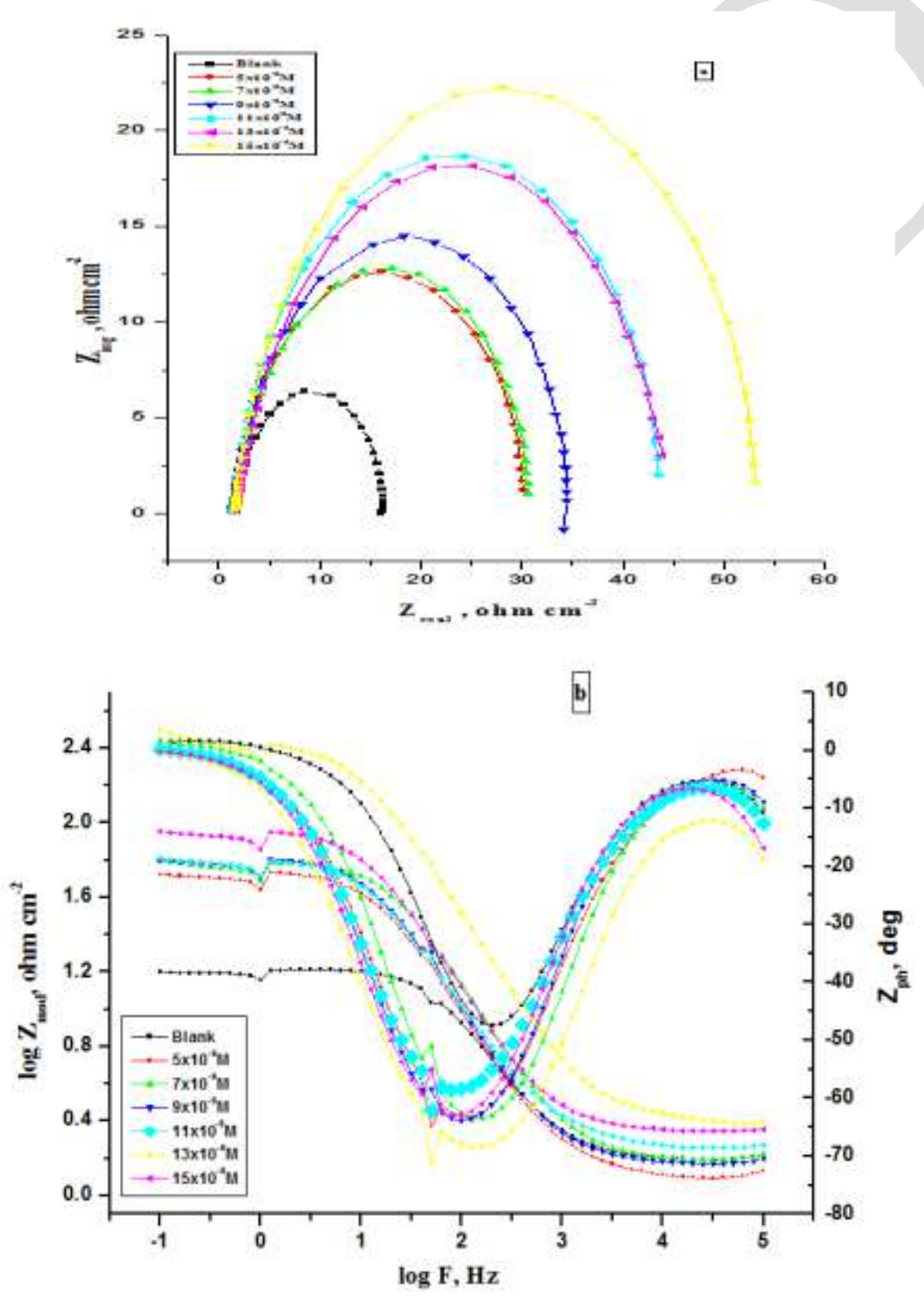

Fig 2: EIS Nyquist plots (a) and Bode plots (b) for C-steel surface in $2 \mathrm{M} \mathrm{HCl}$ in the absence and presence of different concentrations of compound (1) at $25 \pm 0.1{ }^{\circ} \mathrm{C}$. 
The Nyquist plots do not yield perfect semicircles as expected from the theory of EIS. The deviation from ideal semicircle was generally attributed to the frequency dispersion as well as to the inhomogenities of the surface. EIS spectra of the organic additives were analyzed using the equivalent circuit, Figure 3, which represents a single charge transfer reaction and fits well with our experimental results. The constant phase element, CPE, is introduced in the circuit instead of a pure double layer capacitor to give a more accurate fit [42]. The double layer capacitance, $\mathrm{C}_{\mathrm{dl}}$, is calculated from Eq. (2):

$$
\mathrm{C}_{\mathrm{dl}}=\mathrm{Y}_{\mathrm{o}} \omega^{\mathrm{n}-1} / \sin [\mathrm{n}(\pi / 2)]
$$

where $Y_{o}$ is the magnitude of the CPE, $\omega=2 \pi f_{\max }, f_{\max }$ is the frequency at which the imaginary component of the impedance is maximal and the factor $\mathrm{n}$ is an adjustable parameter that usually lies between 0.50 and 1.0.

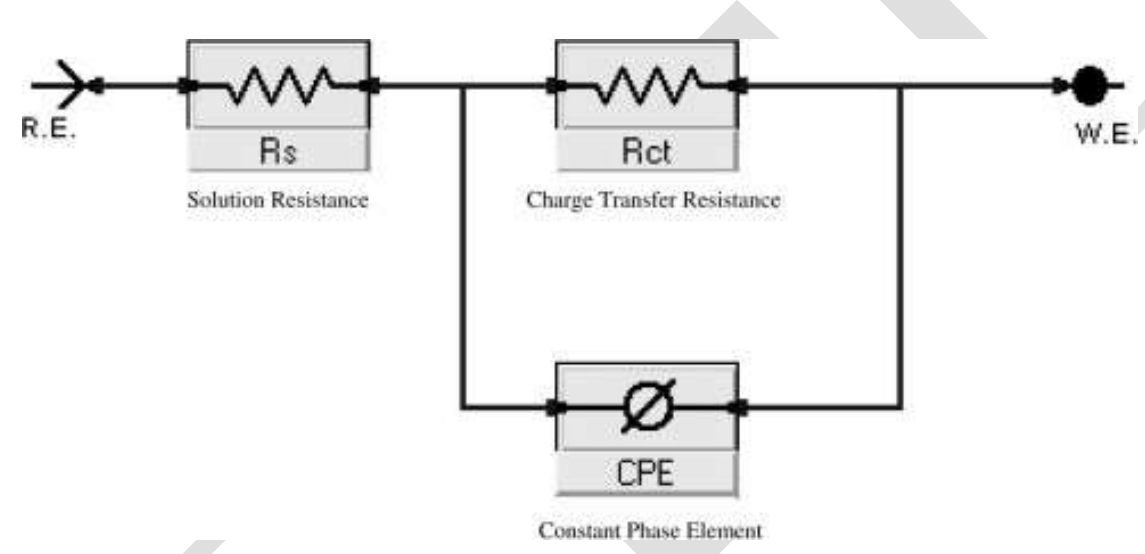

Fig 3: Equivalent circuit model used to fit experimental EIS.

After analyzing the shape of the Nyquist plots, it is concluded that the curves approximated by a single capacitive semicircle, showing that the corrosion process was mainly charged-transfer controlled [43-45]. The general shape of the curves is very similar for all samples (in presence or absence of inhibitors at different immersion times) indicating that no change in the corrosion mechanism [46]. From the impedance data (Table 3), we conclude that the value of Rct increases with increasing the concentration of the inhibitors and this indicates an increase in \% IE, which in concord with the Polarization results obtained. In fact, the presence of inhibitors enhances the value of $R_{c t}$ in acidic solution. Values of double layer capacitance are also brought down to the maximum extent in the presence of inhibitor and the decrease in the values of CPE follows the order similar to that obtained for $\mathrm{i}_{\text {corr }}$ in this study. The decrease in $\mathrm{CPE} / \mathrm{C}_{\mathrm{dl}}$ results from a decrease in local dielectric constant and/or an increase in the thickness of the double layer, suggesting that thiosemicarbazide derivatives inhibit the C-steel corrosion by adsorption at metal/acid [47, 48]. The main advantages of EIS are to follow the corrosion behavior of the metal with constant time. The inhibition efficiency was calculated from the charge transfer resistance data from Eq. (3) [49]:

$\% \mathrm{IE}_{\mathrm{EIS}}=\left[1-\left(\mathrm{R}_{\mathrm{ct}}^{\circ} / \mathrm{R}_{\mathrm{ct}}\right)\right] \times 100$ 
Table 3.Electrochemical kinetic parameters obtained by EIS technique for C-steel in $2 \mathrm{M} \mathrm{HCl}$ without and with various concentrations of compounds (1-2) at $25 \pm 0.1^{\circ} \mathrm{C}$.

\begin{tabular}{|c|c|c|c|c|c|c|c|c|}
\hline Inhibitors & Conc. (M) & $\begin{array}{c}\mathrm{R}_{\mathrm{S}} \\
\left(\Omega \mathrm{cm}^{2}\right)\end{array}$ & $Y_{0 \times 10^{-3}}$ & $\mathrm{n}$ & $\begin{array}{c}\mathrm{R}_{\mathrm{ct}} \\
\left(\Omega \mathrm{cm}^{2}\right)\end{array}$ & $\begin{array}{l}\mathrm{C}_{\mathrm{dl} \times 10^{-3}} \\
\left(\mu \mathrm{Fcm}^{-2}\right)\end{array}$ & $\theta$ & $\% \mathrm{IE}_{\mathrm{EIS}}$ \\
\hline \multirow[t]{7}{*}{ Compound 1} & Blank & 11.9 & 134.10 & 805 & 1.013 & 99.32 & ----- & ------ \\
\hline & $5 \times 10^{-6}$ & 9.5 & 123.40 & 795 & 1.824 & 55.19 & 0.4446 & 44.46 \\
\hline & $7 \times 10^{-6}$ & 9.6 & 148.70 & 807 & 1.895 & 53.14 & 0.4654 & 46.54 \\
\hline & $9 \times 10^{-6}$ & 1.5 & 33.22 & 846 & 2.068 & 48.59 & 0.5101 & $\begin{array}{l}51.01 \\
\end{array}$ \\
\hline & $11 \times 10^{-6}$ & 1.7 & 33.01 & 833 & 2.256 & 44.55 & 0.5509 & 55.09 \\
\hline & $13 \times 10^{-6}$ & 1.6 & 30.59 & 826 & 2.808 & 35.80 & 0.6392 & 63.92 \\
\hline & $15 \times 10^{-6}$ & 11.9 & 289.80 & 158 & 6.872 & 17.824 & 0.8525 & 85.25 \\
\hline \multirow{6}{*}{ Compound 2} & $5 \times 10^{-6}$ & 2.7 & 85.72 & 804 & 1.679 & 59.92 & 0.3966 & 39.66 \\
\hline & $7 \times 10^{-6}$ & 10.0 & 90.12 & 802 & 1.693 & 59.43 & 0.4016 & 40.16 \\
\hline & $9 \times 10^{-6}$ & 9.9 & 163.6 & 767 & 1.737 & 57.99 & 0.4153 & 41.53 \\
\hline & $11 \times 10^{-6}$ & 1.4 & 39.83 & 858 & 1.777 & 56.55 & 0.4299 & 42.99 \\
\hline & $13 \times 10^{-6}$ & 10.1 & 110.20 & 803 & 1.778 & 56,63 & 0.4302 & 43.02 \\
\hline & $15 \times 10^{-6}$ & 1.4 & 37.28 & 845 & 1.779 & 56.49 & 0.4305 & 43.05 \\
\hline
\end{tabular}

Where $\mathrm{R}_{\text {ct }}^{\mathrm{o}}$ and $\mathrm{R}_{\mathrm{ct}}$ are the charge-transfer resistance values without and with inhibitor, respectively.

\subsection{Electrochemical frequency modulation technique (EFM)}

EFM is a nondestructive corrosion measurement method that can directly and quickly determine the corrosion current values without prior knowledge of Tafel slopes, and with only a small polarizing signal. These advantages of EFM technique make it an ideal candidate for online corrosion monitoring [50]. The great strength of the EFM is the causality factors which serve as an internal check on the validity of EFM measurement. The causality factors $\mathrm{CF}-2$ and $\mathrm{CF}-3$ are calculated from the frequency spectrum of the current responses.

Figure 4 shows the EFM Intermodulation spectrums of C-steel in $2 \mathrm{M} \mathrm{HCl}$ solution containing different concentrations of compound (1). Similar curves were obtained for other compounds (not shown). The harmonic and intermodulation peaks are clearly visible and are much larger than the background noise. The two large peaks, with amplitude of about 200 $\mu \mathrm{A}$, are the response to the 40 and $100 \mathrm{mHz}(2$ and $5 \mathrm{~Hz}$ ) excitation frequencies. It is important to note that between the peaks there is nearly no current response $(<100 \mathrm{nA})$. The experimental EFM data were treated using two different models: complete diffusion control of the cathodic reaction and the "activation" model. For the latter, a set of three non-linear equations had been solved, assuming that the corrosion potential does not change due to the polarization of the working electrode [51]. The larger peaks were used to calculate the corrosion current density $\left(i_{\text {corr }}\right)$, the Tafel slopes $\left(\beta_{\mathrm{c}}\right.$ and $\left.\beta_{\mathrm{a}}\right)$ and the causality factors $(\mathrm{CF}-2$ and CF-3).These electrochemical parameters were listed in Table 4. 

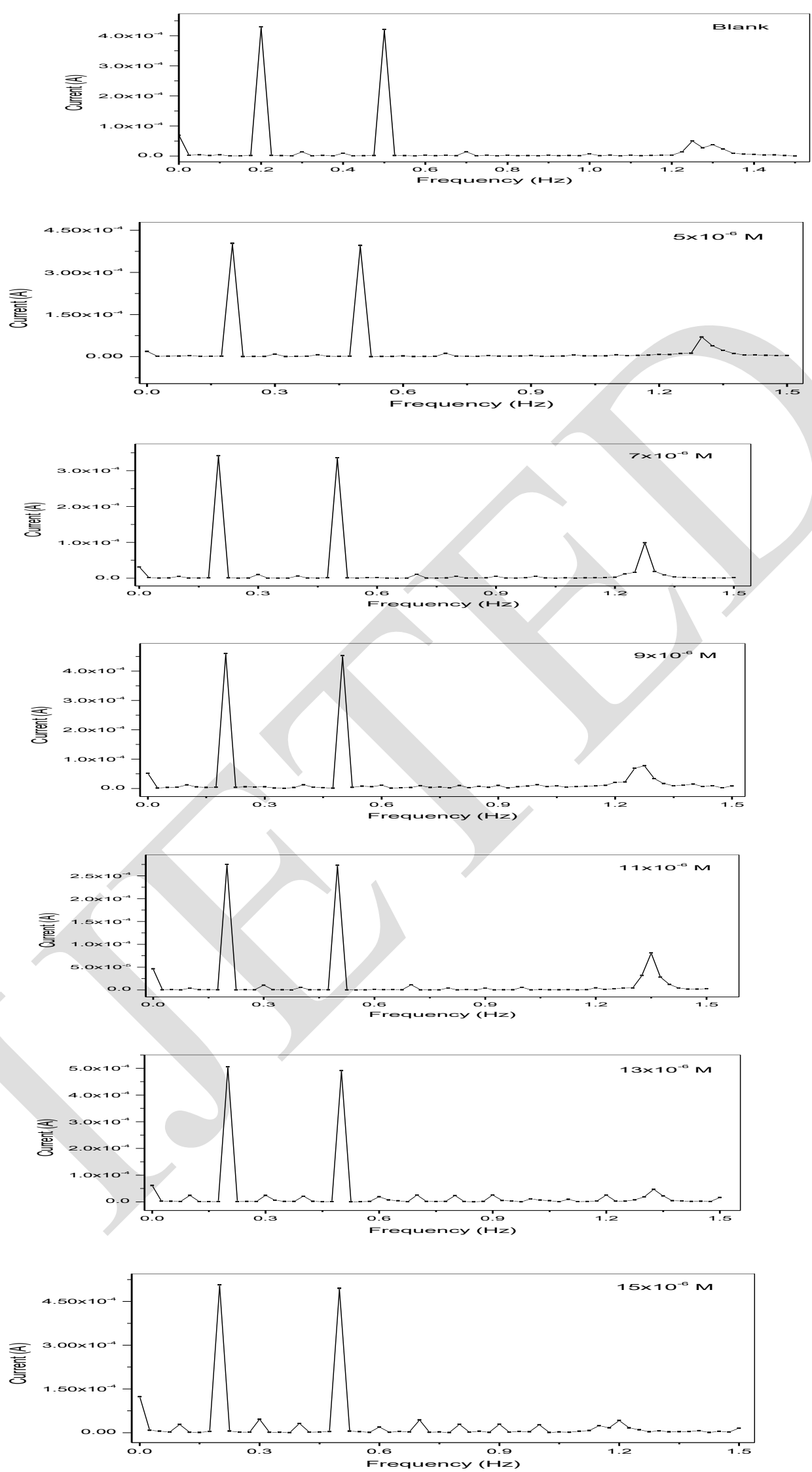

Fig 4: EFM spectra for $\mathrm{C}$-steel in $2 \mathrm{M} \mathrm{HCl}$ in the absence and presence of different concentration of compound (1) at $25 \pm 0.1^{\circ} \mathrm{C}$. 
The data presented in Table 4 obviously show that, the addition of any one of tested compounds at a given concentration to the acidic solution decreases the corrosion current density, indicating that these compounds inhibit the corrosion of $\mathrm{C}$-steel in $2 \mathrm{M} \mathrm{HCl}$ through adsorption. The causality factors obtained under different experimental conditions are approximately equal to the theoretical values ( 2 and 3 ) indicating that the measured data are verified and of good quality. The inhibition efficiencies\% $\mathrm{IE}_{\mathrm{EFM}}$ increase by increasing the inhibitor concentrations and was calculated as from Eq. (4)

$\% \mathrm{IE}_{\mathrm{EFM}}=\left[1-\left(\mathrm{i}_{\text {corr }} i^{\mathrm{o}}\right.\right.$ corr $\left.)\right] \times 100$

Where $\mathrm{i}_{\text {corr }}^{\mathrm{o}}$ and $\mathrm{i}_{\text {corr }}$ are corrosion current densities in the absence and presence of inhibitor, respectively.

The inhibition sufficiency obtained from this method is in the order: 4-phenylthiosemicarbazide > 4-allyl-thiosemicarbazide.

Table 4. Electrochemical kinetic parameters obtained by EFM technique for C-steel in $2 \mathrm{M}$ $\mathrm{HCl}$ without and with various concentrations of compounds (1-2) at $25 \pm 0.1{ }^{\circ} \mathrm{C}$.

\begin{tabular}{|c|c|c|c|c|c|c|c|c|}
\hline Inhibitors & $\begin{array}{l}\text { Conc. } \\
\text { (M) }\end{array}$ & $\begin{array}{c}\mathrm{i}_{\text {corr }} \\
\left(\mu \mathrm{A} \mathrm{cm}^{-2}\right)\end{array}$ & $\begin{array}{c}\beta_{\mathrm{a}} \\
\left.(\mathrm{mV} \mathrm{dec})^{-1}\right)\end{array}$ & $\begin{array}{c}\beta_{\mathrm{c}} \\
\left(\mathrm{mV} \operatorname{dec}^{-1}\right)\end{array}$ & $\mathrm{CF}-2$ & CF-3 & $\theta$ & $\% \mathrm{IE}_{\mathrm{EFM}}$ \\
\hline \multirow[t]{7}{*}{ Compound 1} & Blank & 49.38 & 81 & 195 & 1.90 & 2.70 & - & - \\
\hline & $5 \times 10^{-6}$ & 15.78 & 116 & 237 & 1.92 & 2.92 & 0.6804 & 68.04 \\
\hline & $7 \times 10^{-6}$ & 14.83 & 93 & 131 & 2.19 & 2.90 & 0.6996 & 69.96 \\
\hline & $9 \times 10^{-6}$ & 14.53 & 90 & 134 & 1.99 & 2.98 & 0.7057 & 70.57 \\
\hline & $11 \times 10^{-6}$ & 13.82 & 85 & 131 & 1.97 & 2.54 & 0.7201 & 72.01 \\
\hline & $13 \times 10^{-6}$ & 13.50 & 90 & 149 & 1.69 & 2.92 & 0.7266 & 72.66 \\
\hline & $15 \times 10^{-6}$ & 12.62 & 99 & 150 & 1.97 & 3.03 & 0.7444 & 74.44 \\
\hline \multirow{6}{*}{ Compound 2} & $5 \times 10^{-6}$ & 19.72 & 90 & 191 & 1.89 & 3.00 & 0.6004 & 60.00 \\
\hline & $7 \times 10^{-6}$ & 18.45 & 112 & 189 & 1.96 & 2.89 & 0.6263 & 62.63 \\
\hline & $9 \times 10^{-6}$ & 18.27 & 80 & 133 & 1.85 & 2.91 & 0.6300 & 63.00 \\
\hline & $11 \times 10^{-6}$ & 18 & 109 & 180 & 2.003 & 3.04 & 0.6354 & 63.54 \\
\hline & $13 \times 10^{-6}$ & 17.74 & 112 & 212 & 1.89 & 2.90 & 0.6404 & 64.04 \\
\hline & $15 \times 10^{-6}$ & 16.11 & 172 & 272 & 1.79 & 2.80 & 0.6737 & 67.37 \\
\hline
\end{tabular}

\subsubsection{Adsorption isotherm}

Adsorption isotherms provide important information about the interaction between the inhibitor molecules and the C-steel surface. The $\theta$ values obtained from EFM technique have been used to explain the best isotherm that describes the adsorption process. In order to determine the best adsorption isotherm, which describe the adsorption of studied thiosemicarbazide derivatives on the c-steel surface, a number of adsorption isotherm models such as, Langmuir, Freundlich and Temkin, have been verified. However, the adequate model was found to be Langmuir. 
Equation (5) describes the linear form of Langmuir isotherm

$\mathrm{C}_{\mathrm{inh}} / \boldsymbol{\Theta}=1 / \mathrm{K}_{\mathrm{ads}}+\mathrm{C}_{\mathrm{inh}}$

Where $C_{\text {inh }}$ stands for inhibitor concentration, $\Theta$ is the surface coverage and $K_{a d s}$ is the adsorption equilibrium constant.

Free energy change of adsorption $\Delta \mathrm{G}_{\mathrm{ads}}$ is calculated by equation (6)

$\Delta \mathrm{G}_{\mathrm{ads}}=-\mathrm{RT} \ln 55.5 \mathrm{~K}_{\mathrm{ads}}$

Where $\mathrm{T}$ is the absolute temperature and $\mathrm{R}$ is the universal gas constant. Figure 5 proves that the adsorption behavior of both studied inhibitors obey Langmuir model. Values of $\Delta \mathrm{G}_{\mathrm{ads}}$ were determined as $-44.5 \mathrm{kj} / \mathrm{mole}$ and $-40.1 \mathrm{kj} / \mathrm{mole}$ for compound 1 and compound 2 , respectively. These values indicate that the adsorption of both compounds is a chemosprtion and spontaneous process [52]. It also proves that adsorption of compound (1) is more spontaneous and stronger than compound (2).

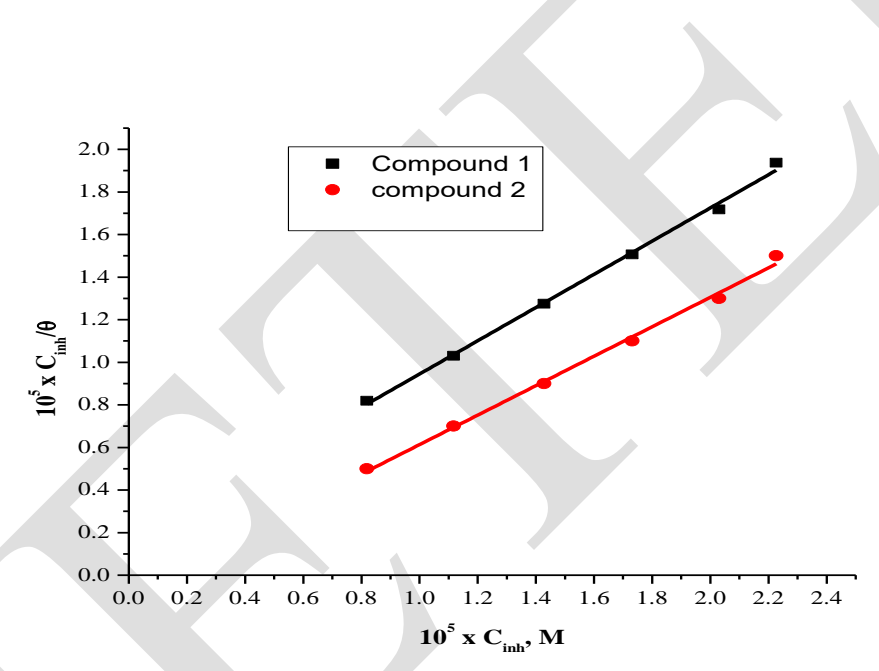

Fig 5: Langmuir adsorption isotherm for the thiosemicarbazide derivatives.

\subsection{Theoretical study}

The optimized molecular structures of the studied molecules using B3LYP/6-31G* methods are shown in Figure 6. The calculated quantum chemical indices $\mathrm{E}_{\mathrm{HOMO}}, \mathrm{E}_{\mathrm{LumO}}, \mathrm{E}_{\mathrm{L}^{-}}$ $\mathrm{E}_{\mathrm{H}}$, global hardness, total energies and dipole moment are given in Table 5, Mulliken atomic charges on, nitrogen, sulphur and carbon atoms are shown in Table 6. It has been proven that local electron densities or charges are important, in many chemical reactions and physicochemical properties of compounds [53]. Inhibition action of organic molecules can be explained by the adsorption on metal surface. Since the surface of the steel is positively charged in acidic solution [54], Table 6 shows that all nitrogen, sulphur and carbon atoms of thiosemicarbazide derivatives carry the negative charges, this indicate that these atoms are the negative charge centers which could offer electrons to the steel surface to form a coordination type of bond. 


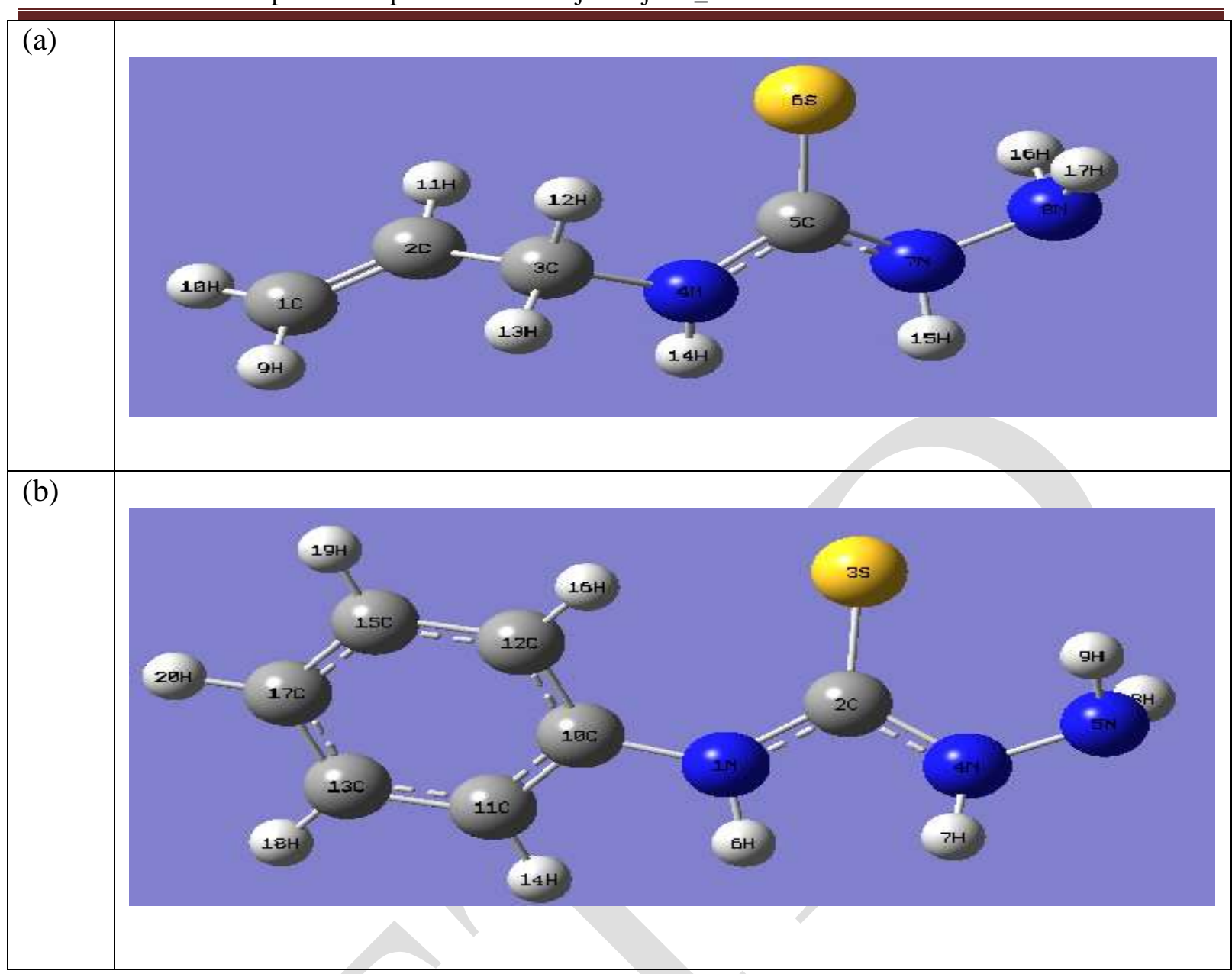

Fig 6: The optimized structure of thiosemicarbazides by B3LYP/6-31G* (a) 4-allylThiosemicarbazide (b) 4-phenyl-Thiosemicarbazide.

Another important point to be considered in the energy level terms is gap between the HOMO and LUMO energies for the studies molecules. Cherry et al. [55] have used the concept of LUMO-HOMO energy gap in developing theoretical models which is capable of explaining the structure and conformation barriers in many molecular systems qualitatively. Low absolute value of the energy band gap $(\Delta \mathrm{E})$ gives good inhibition efficiencies, because the energy required to remove an electron from the last occupied orbital will be low. According to the data in Table 5, there is a good correlation in LUMO-HOMO energy gap by these methods in gas phase, it can be seen that 4-phenyl-thiosemicarbazides is best inhibitor and has smaller LUMO- HOMO gap i.e (4.9926 eV), but the 4-allyl-thiosemicarbazide is less inhibitor and has higher LUMO- HOMO gap i.e (5.4884 eV). The inhibition efficiencies increases as the $E_{L}-E_{H}$ values decrease, which indicates the stability of formed complexes between thiosemicarbazides and steel in acid media, i.e the order of inhibition efficiencies as follows: 4-phenyl-thiosemicarbazide > 4-allyl-thiosemicarbazide (compare this with experimental). This indicates that the best correlations between experimental and calculated inhibition efficiencies were obtained by using B3LYP/6-31G* in gas phase for thiosemicarbazides, correlations are almost in the same order. Correlation coefficients greater than $60 \%$ were well accepted in quantum chemical calculations of corrosion studies [56]. 
Table 5. Calculated Quantum Chemical Parameters for the thiosemicarbazides by B3LYP/6-31G* Method

\begin{tabular}{|c|c|c|c|c|c|c|}
\hline Inhibitor & $\begin{array}{c}\mathrm{E}_{\mathrm{LUMO}} \\
(\mathrm{eV})\end{array}$ & $\begin{array}{c}\mathrm{E}_{\mathrm{HOMO}} \\
(\mathrm{eV})\end{array}$ & $\begin{array}{c}\mathrm{E}_{\mathrm{L}}-\mathrm{E}_{\mathrm{H}} \\
(\mathrm{eV})\end{array}$ & $\begin{array}{c}\text { Hardness } \\
\mathrm{eV}\end{array}$ & $\begin{array}{c}\text { Dipole } \\
\text { Moment } \\
(\mathrm{D})\end{array}$ & $\begin{array}{c}\text { Total energy } \\
\mathrm{eV}\end{array}$ \\
\hline Compound 1 & -0.7752 & -5.7678 & 4.9926 & 2.4963 & 3.6113 & -22709.4514 \\
\hline Compound 2 & -0.2212 & -5.7096 & 5.4884 & 2.7442 & 3.96770 & -19598.0917 \\
\hline
\end{tabular}

High $\mathrm{E}_{\mathrm{HOMO}}$ values indicate that the molecule tends to donate electrons to appropriate acceptor molecules with low energy empty molecular orbital. Increasing values of the $\mathrm{E}_{\mathrm{HOMO}}$ facilitate adsorption (and therefore inhibition) by influencing the transport process through the adsorbed layer; low LUMO energy indicates the ability of the molecules to accept electrons. The results obtained by B3LYP/6-31G* methods in gas phase, (Table 5) show that 4-phenyl-thiosemicarbazides has higher $\mathrm{HOMO}$ energy $\left(\mathrm{E}_{\mathrm{HOMO}}=-5.7678 \mathrm{eV}\right)$ and lower LUMO energy $\left(\mathrm{E}_{\mathrm{LUMO}}=-0.7752 \mathrm{eV}\right)$ than 4-allyl-thiosemicarbazide derivative. Figure 7 shows the shapes of highest occupied molecular orbital (HOMO) and the lowest unoccupied molecular orbital (LUMO) of the compounds under investigations. From these figures it can be concluded that the compounds adsorbed on the steel surface by using the thiosemicarbazides moiety which contains the heteroatom nitrogen and sulphur.

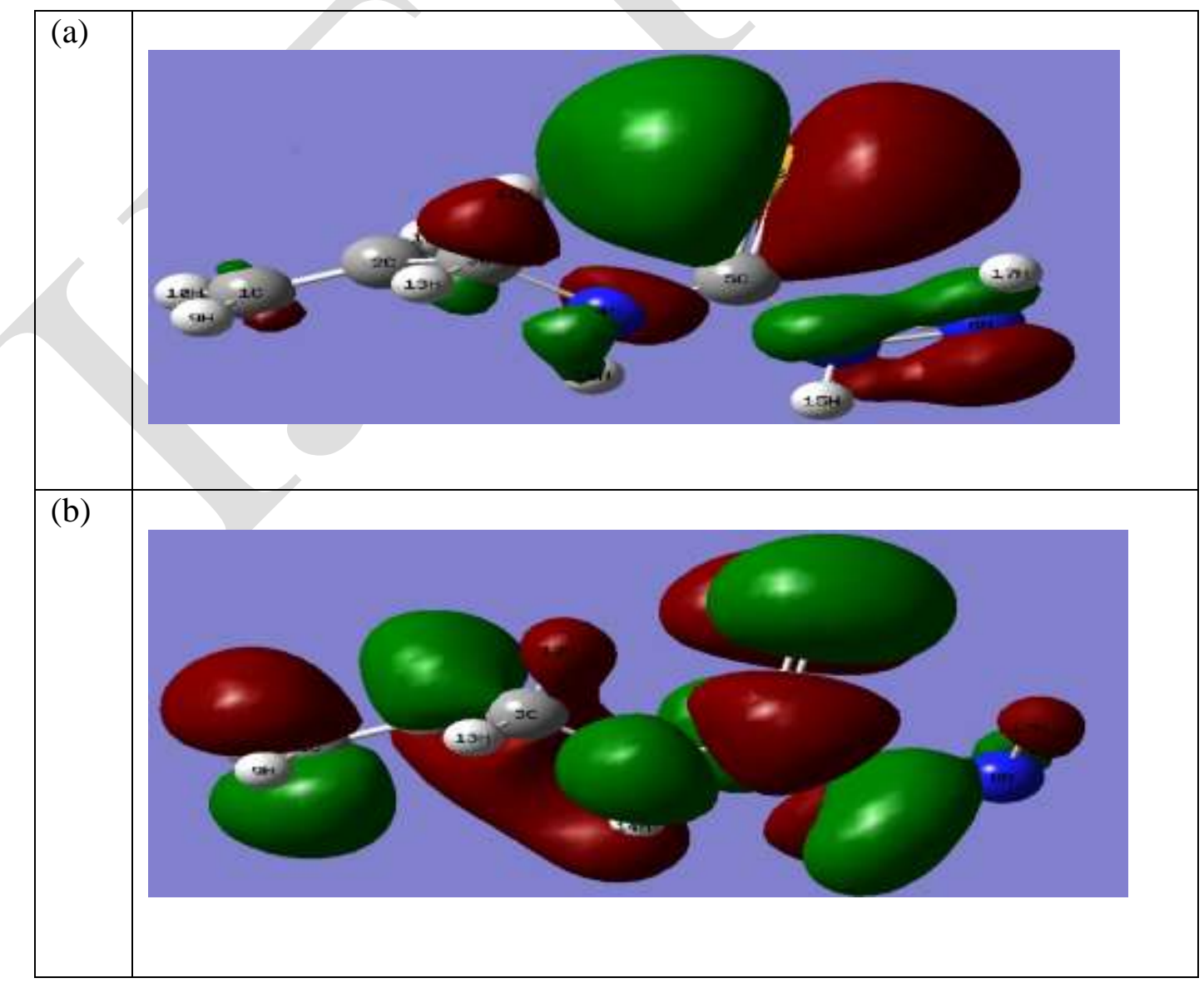




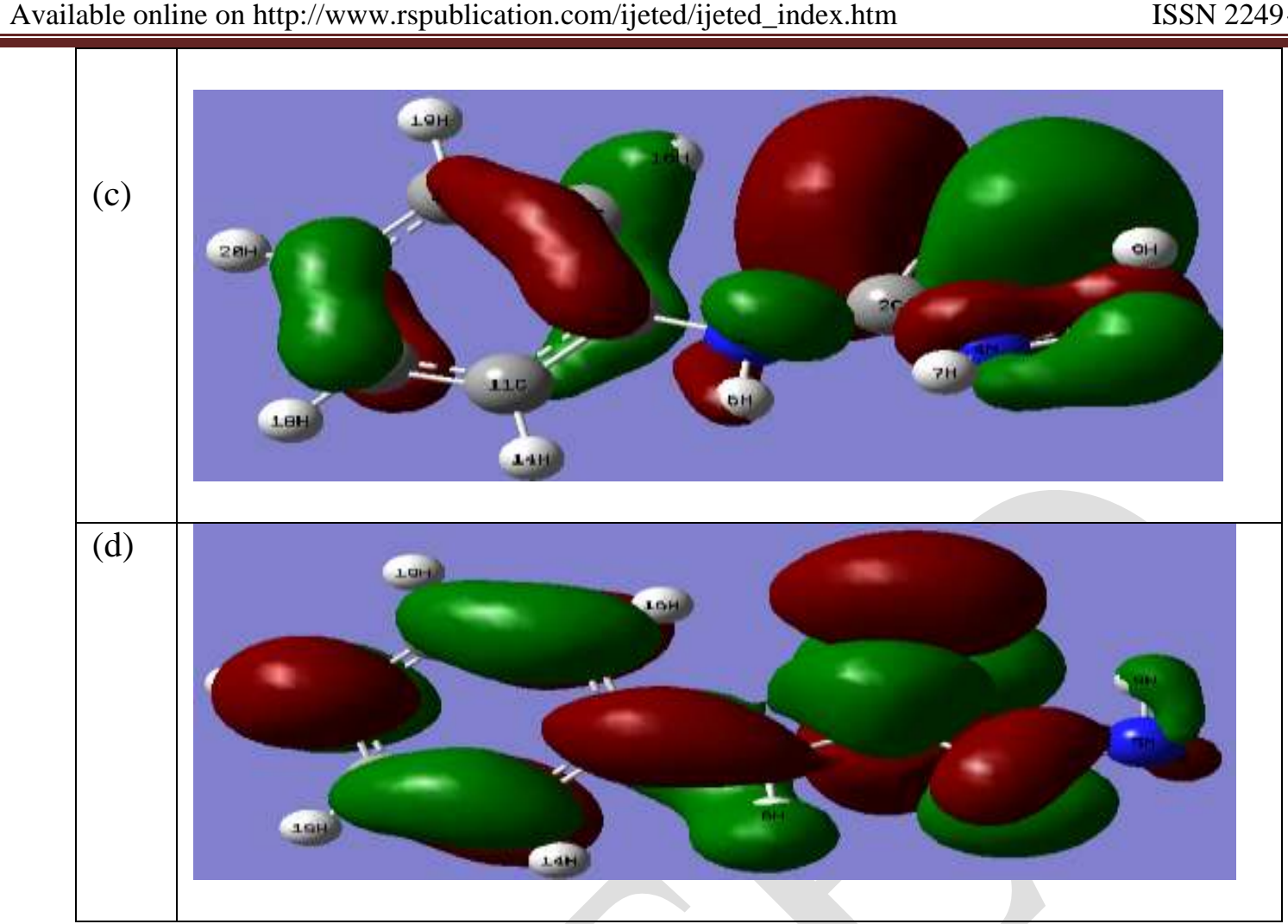

Fig 7. Frontier molecular orbital diagrams of 4-allyl- and 4-phenylthiosemicarbazides by the B3LYP/6-31G* model chemistry (a) HOMO of 4-allyl- thiosemicarbazide (b) LUMO of 4-allyl-thiosemicarbazide (c) HOMO of 4-phenyl- thiosemicarbazide (d) LUMO of 4- phenylthiosemicarbazide

Quantum chemical calculation reveals that the substitution of allyl- group by phenylgroup results in a great increase of HOMO energy level (and a decrease of energy of the gap $\left.\mathrm{E}_{\mathrm{LUMO}^{-}} \mathrm{E}_{\mathrm{HOMO}}\right)$ obviously. The increase of inhibition efficiency due to allyl/Ph substitution should arise from the increase of HOMO level energy, low LUMO energy and low $\Delta \mathrm{E}$ implying the ability of 4-phenyl-thiosemicarbazide to offer free electrons to the metal surface. The result of the high inhibition efficiency in phenyl derivative is not surprising as a phenyl group is an electron donor, which has $\pi$-orbital able to overlap with the metal d-orbital resulting in stronger adsorption with $\mathrm{C}$ - steel. Thus, the order of inhibition efficiency is 4phenyl-thiosemicarbazide > 4-allyl-thiosemicarbazide, as can be deduced above, which agreed with experimental ones.

Table 6. Mulliken atomic charges of thiosemicarbazides by B3LYP/6-31G*

\begin{tabular}{|c|c|c|c|c|c|c|c|c|c|c|c|}
\hline Compound 1 & $\mathrm{N} 1$ & $\mathrm{C} 2$ & $\mathrm{~S} 3$ & $\mathrm{~N} 4$ & $\mathrm{~N} 5$ & $\mathrm{C} 10$ & $\mathrm{C} 11$ & $\mathrm{C} 12$ & $\mathrm{C} 13$ & $\mathrm{C} 15$ & C17 \\
\hline & -0.7027 & 0.3605 & - & - & - & 0.3559 & - & - & - & - & - \\
& & & 0.2818 & 0.4813 & 0.5533 & & 0.1903 & 0.1304 & 0.1343 & 0.1463 & 0.1256 \\
\hline Compound 2 & $\mathrm{C} 1$ & $\mathrm{C} 2$ & $\mathrm{C} 3$ & $\mathrm{~N} 4$ & $\mathrm{C} 5$ & $\mathrm{~S} 6$ & $\mathrm{~N} 7$ & $\mathrm{~N} 8$ & & & \\
& -0.3399 & - & - & - & 0.3621 & - & - & - & & & \\
& & 0.0496 & 0.1878 & 0.5692 & & 0.3122 & 0.4787 & 0.5549 & & & \\
\hline
\end{tabular}


Another property calculated for these molecules is the global hardness $\eta$, calculated as $\Delta \mathrm{E} / 2$, which is parameter that gives important information about the reactive behavior of the molecule, and can be defined under the principle of chemical hardness and softness (HSAB) [53], as can be seen in Table 5, the 4-phenyl-thiosemicarbazide exhibits the less hardness value, whereas the 4-allyl-thiosemicarbazide, presents the higher value of hardness this indicate that 4-phenyl-thiosemicarbazide is potential corrosion inhibitor than 4-allylthiosemicarbazide.

\section{5. (SEM) tests}

The micrography given from coins of C-steel without and with of $15 \times 10^{-6} \mathrm{M}$ thiosemicarbazide derivatives after putted for 3 days given in Fig. 8. The surfaces suffer from severe corrosion attack in the blank sample. Due to the stress out when the compound adding in the solution, the morphology of C-steel surfaces is quite unlike from the preceding one, and the tests surfaces were smoother. We observed a film formation which distributed in a random way on the whole alloy surface. This may be interpreted as due to the adsorption of the thiosemicarbazide derivatives on $\mathrm{C}$-steel surface merger into the passive film in order to the active site block on C-steel. Resulting in a lower in the contact among C-steel and the aggressive medium and sequentially obtain best inhibition effect $[57,58]$.

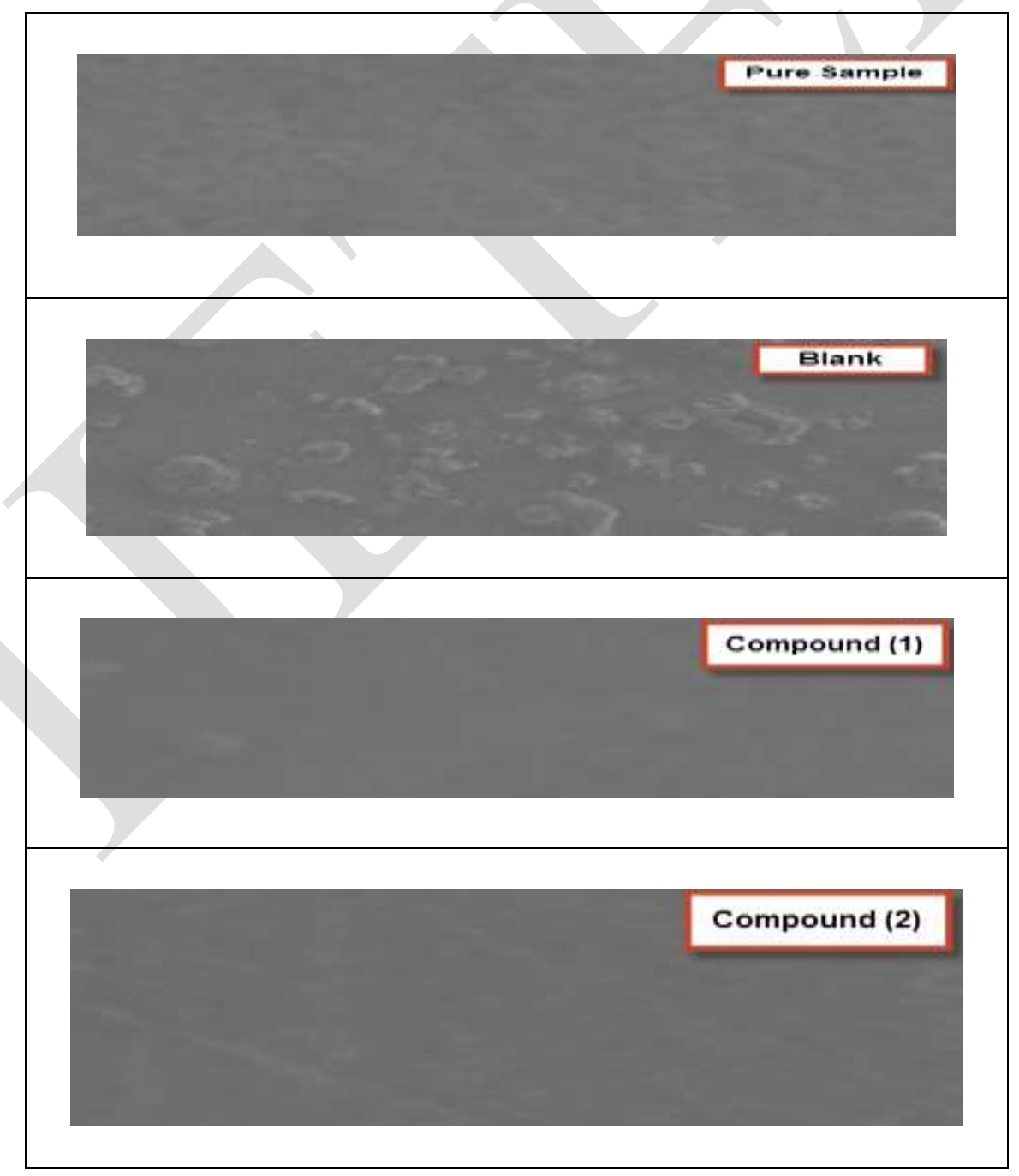

Fig 8. SEM images of $\mathrm{C}$-steel in $2 \mathrm{M} \mathrm{HCl}$ solution after immersion for 3 days without inhibitor and with of $15 \times 10^{-6} \mathrm{M}$ of thiosemicarbazide derivatives. 


\section{6. (EDS) test}

The EDS spectra were utilized to measure the elements found on the surface of Csteel and after 3 days of covered in the lack and attendance of $2 \mathrm{M} \mathrm{HCl}$. Figure 9 gives the EDS result measured on the composition of $\mathrm{C}$-steel only without the acid and inhibitor modified. The EDS record that only oxygen and iron were observed, which given that the passive film found with only $\mathrm{Fe}_{2} \mathrm{O}_{3}$.

The EDS tests of C-steel in $2 \mathrm{M} \mathrm{HCl}$ only and with of $15 \times 10^{-6} \mathrm{M}$ of thiosemicarbazide derivatives portrays in Fig. 9. The spectra give additional lines, lead to the presence of $\mathrm{C}$ (the carbon atoms of thiosemicarbazide derivatives). These values give that the $\mathrm{O}$ and $\mathrm{C}$ atoms covered surface. The elemental observed is record in Table 7.

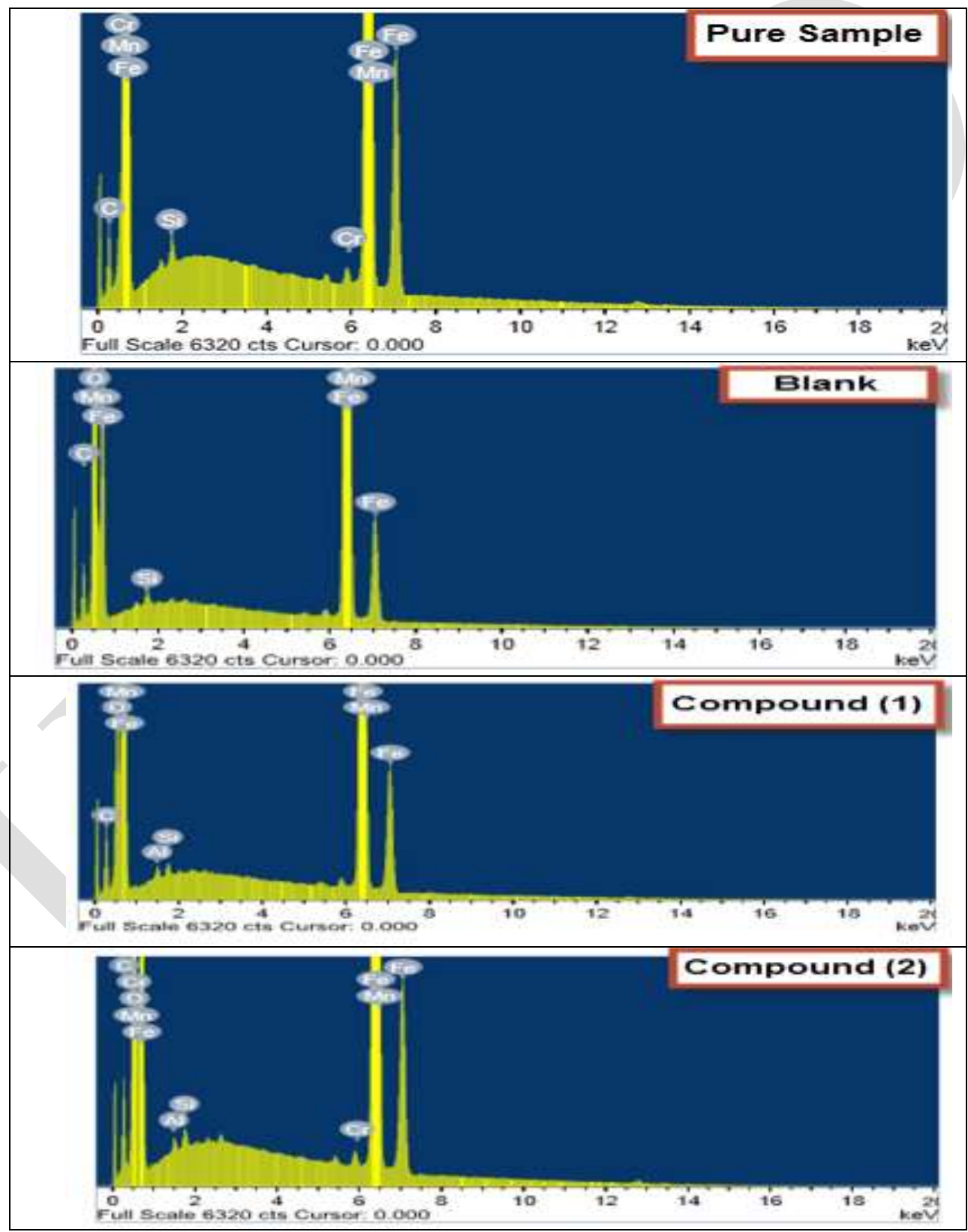

Fig 9. EDS study of $\mathrm{C}$-steel in $2 \mathrm{M} \mathrm{HCl}$ solution after immersion for 3 days without inhibitor and in presence of $15 \times 10^{-6} \mathrm{M}$ of thiosemicarbazide derivatives 
Table 7: Surface composition (weight \%) of C-steel after 3 days of immersion in $2 \mathrm{M} \mathrm{HCl}$ without and with the optimum concentrations of the studied thiosemicarbazide derivatives.

\begin{tabular}{|c|c|c|c|c|c|c|c|}
\hline Weight \% & $\mathrm{C}$ & $\mathrm{O}$ & $\mathrm{Al}$ & $\mathrm{Si}$ & $\mathrm{Cr}$ & $\mathrm{Mn}$ & $\mathrm{Fe}$ \\
\hline Pure Sample & 7.81 & --- & ---- & 0.46 & 0.24 & 0.63 & 90.86 \\
\hline Blank & 8.25 & 29.44 & ---- & 0.28 & ---- & 0.43 & 61.60 \\
\hline Compound (1) & 10.89 & 11.89 & 0.34 & 0.39 & --- & 0.54 & 75.95 \\
\hline Compound (2) & 8.33 & 24.91 & 0.32 & 0.33 & ---- & 0.52 & 65.59 \\
\hline
\end{tabular}

\subsection{Molecular docking}

The docking study showed a favorable interaction between thiosemicarbazide

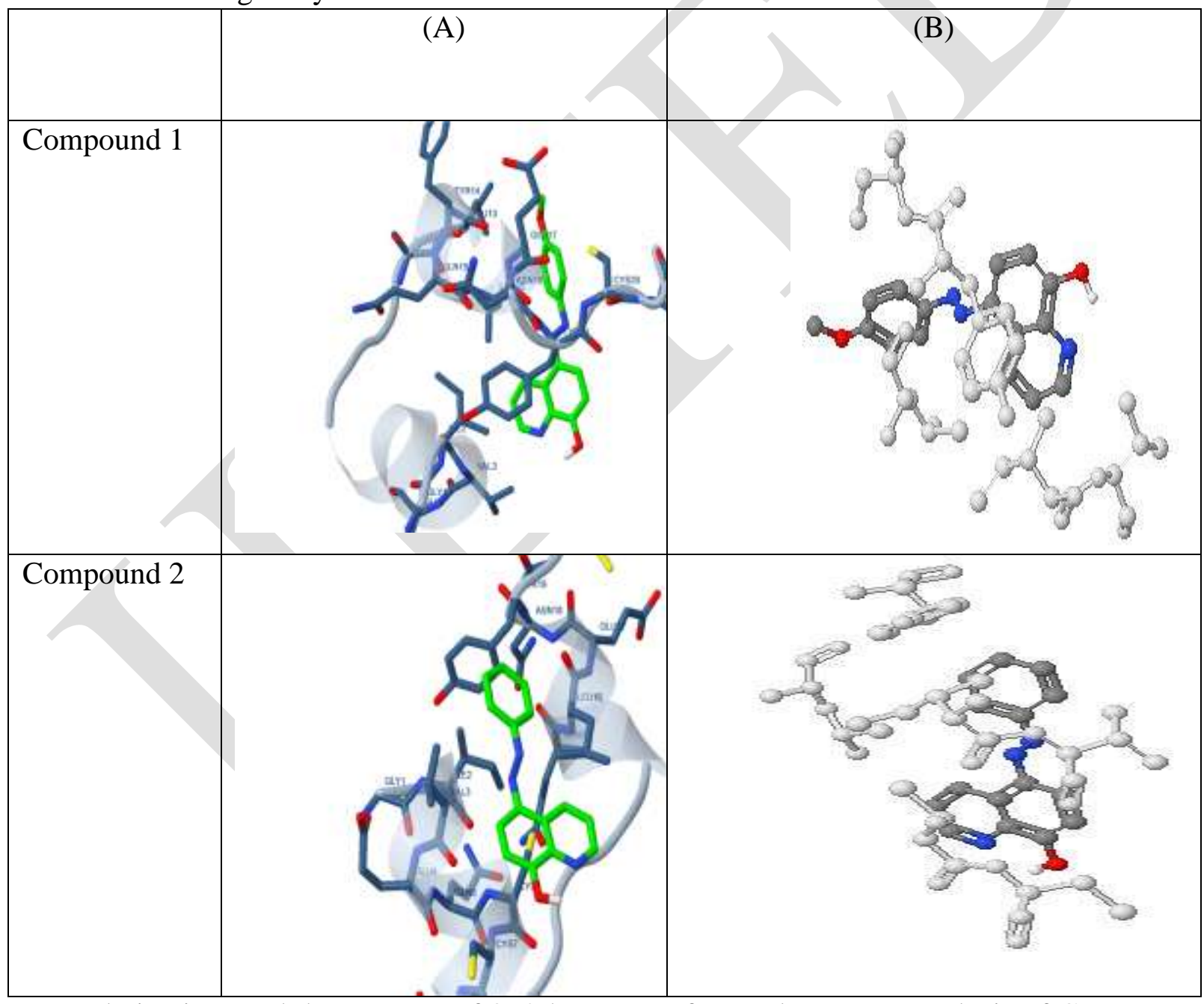

derivatives and the receptor of 3tt8-hormone of crystal structure analysis of $\mathrm{Cu}$ Human Insulin Derivative. The calculated energy is listed in Table 8 and Fig. 10. According to the results obtained in this study, HB plot curve indicated that, the thiosemicarbazide derivatives binds to the proteins hydrogen bond and decomposed interactions energies in $\mathrm{kcal} / \mathrm{mol}$ were existed between the thiosemicarbazide derivatives with $3 \mathrm{tt} 8$ receptor as shown in Fig. 11. The calculated efficiency is favorable where Ki values estimated by AutoDock were compared 
with experimental Ki values, when available, and the Gibbs free energy is negative [59-61]. Also, based on this data, it can propose that interaction between the $3 \mathrm{tt} 8$ receptor and the thiosemicarbazide derivatives is possible. 2D plot curves of docking with thiosemicarbazide derivatives are shown in Fig. 12.

Fig 10: Thiosemicarbazide derivatives (green in (A) and gray in (B)) in interaction with $3 \mathrm{tt} 8$ receptor. (For interpretation of the references to color in this figure legend, the reader is referred to the web version of this article).

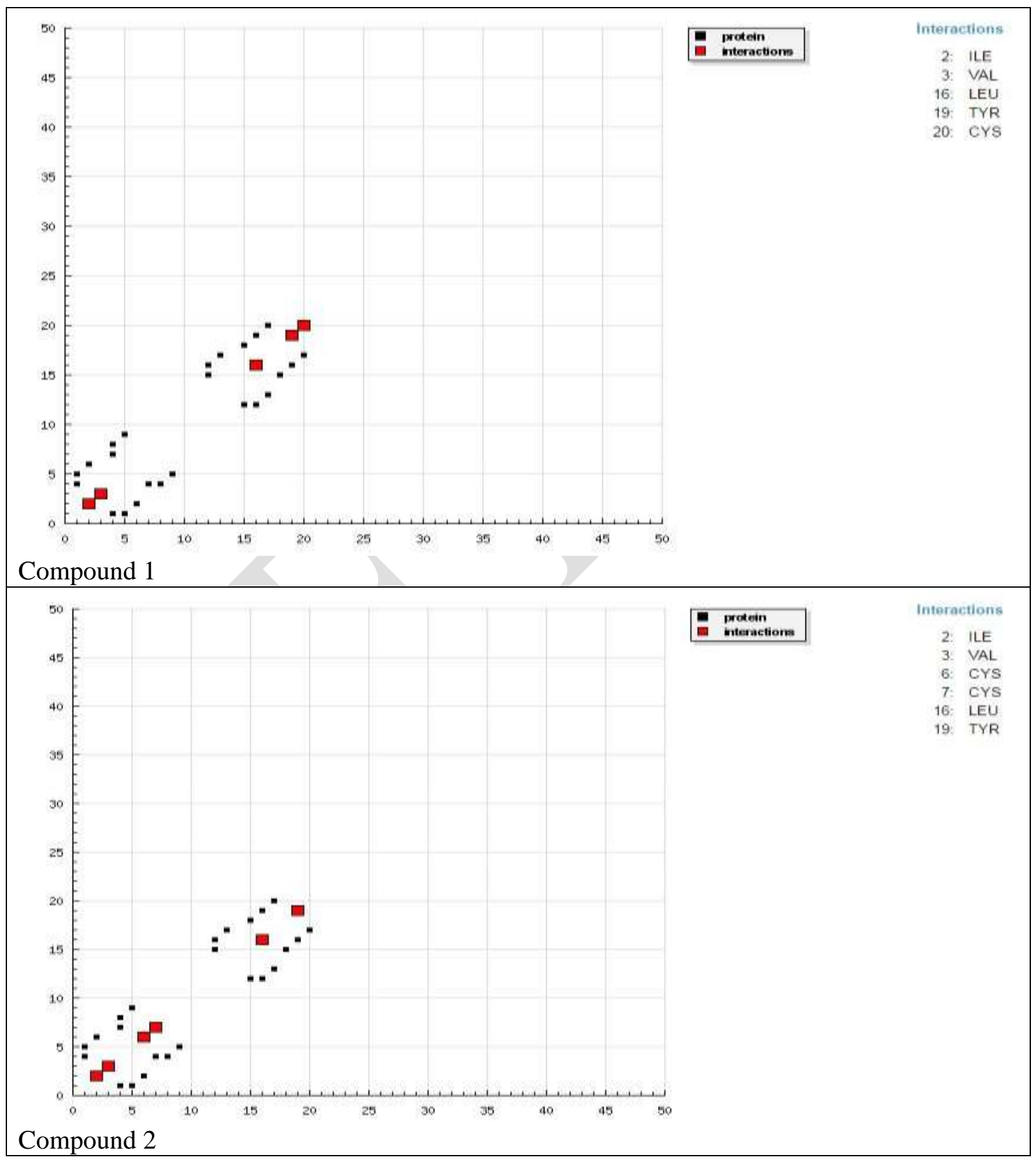


DOI : https://dx.doi.org/10.26808/rs.ed.i8v5.05

International Journal of Emerging Trends in Engineering and Development Available online on http://www.rspublication.com/ijeted/ijeted_index.htm

Fig 11: HB plot of interaction between thiosemicarbazide derivatives with receptor of breast cancer mutant $3 \mathrm{tt} 8$.

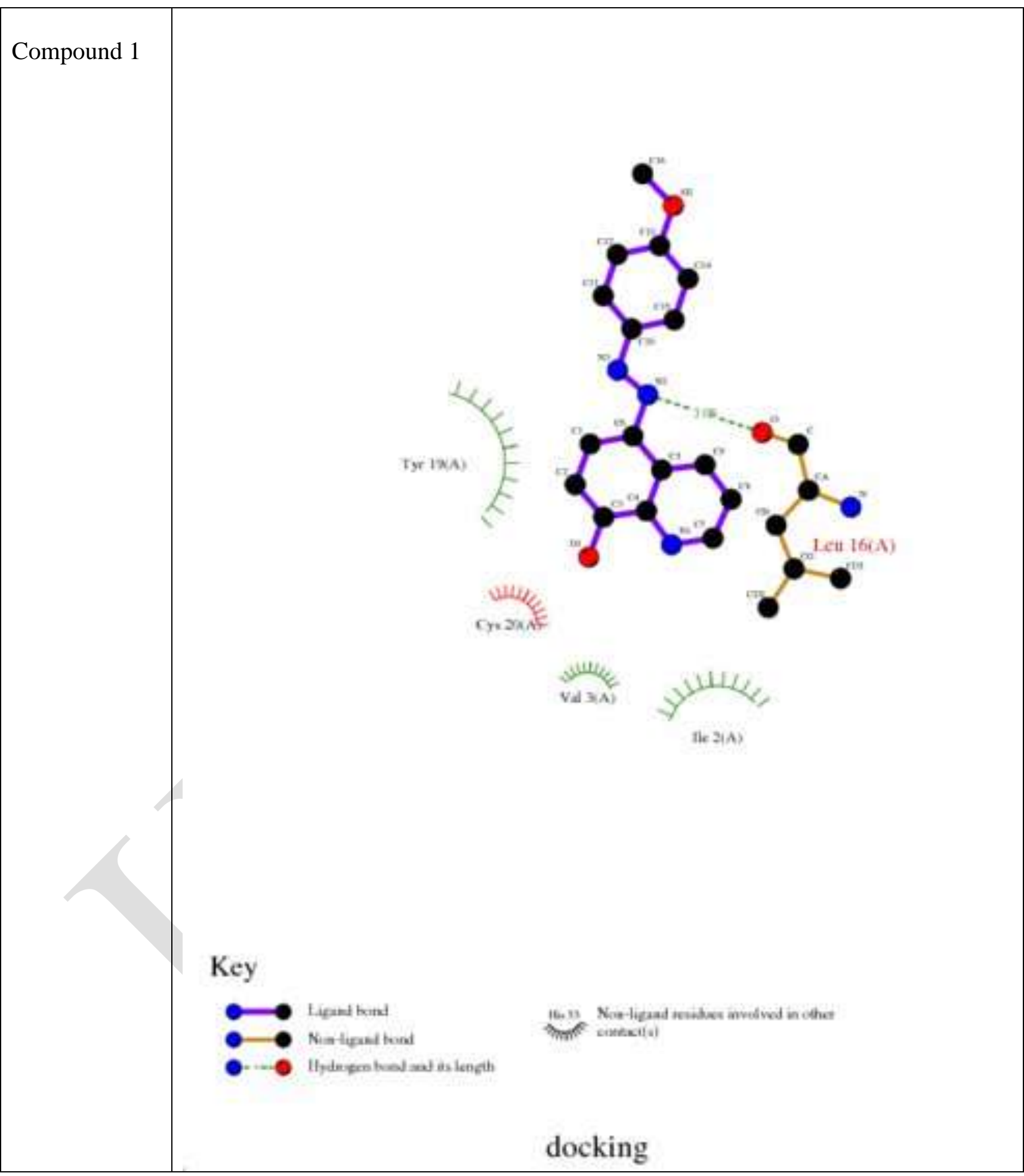




\section{Compound 2}
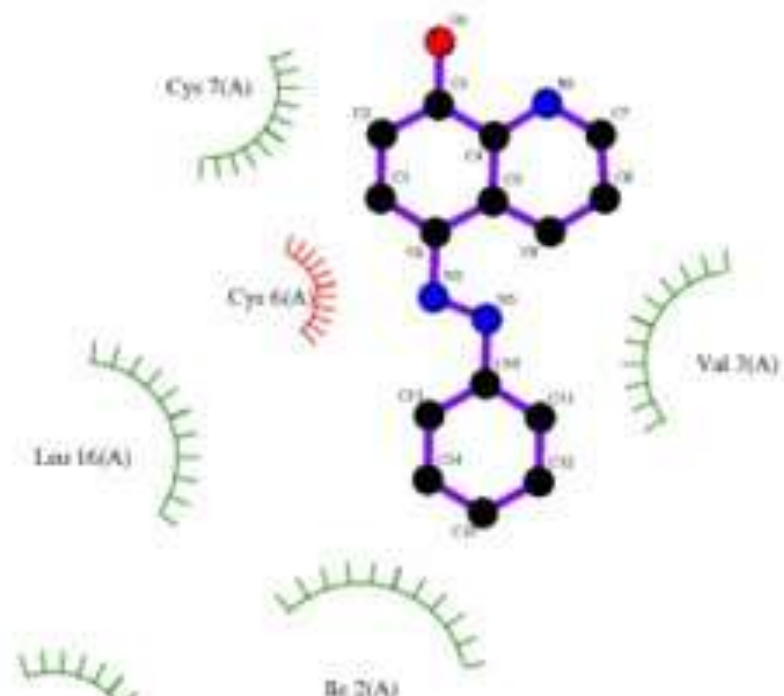

\section{Key}

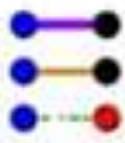

tipant band

Nintlyas tond

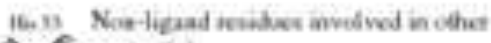

Hpdespon bool and as lenght sonkikilai

\section{docking}

Fig 12: 2D plot of interaction between thiosemicarbazide derivatives with $3 \mathrm{tt} 8$ receptor 
Table 8. Energy values obtained in docking calculations of thiosemicarbazide derivatives with $3 \mathrm{tt} 8$ receptor.

\begin{tabular}{|c|c|c|c|c|c|c|}
\hline Compound & $\begin{array}{c}\text { Est. free energy } \\
\text { of binding } \\
(\mathrm{kcal} / \mathrm{mol})\end{array}$ & $\begin{array}{c}\text { Est. } \\
\text { inhibition } \\
\text { constant }\left(\mathrm{K}_{\mathrm{i}}\right) \\
(\mu \mathrm{M})\end{array}$ & $\begin{array}{c}\text { vdW+ bond+ } \\
\text { desolve } \\
\text { energy } \\
(\mathrm{kcal} / \mathrm{mol})\end{array}$ & $\begin{array}{c}\text { Electrostatic } \\
\text { Energy } \\
(\mathrm{kcal} / \mathrm{mol})\end{array}$ & $\begin{array}{c}\text { Total } \\
\text { intercooled } \\
\text { Energy } \\
(\mathrm{kcal} / \mathrm{mol})\end{array}$ & $\begin{array}{c}\text { Interact } \\
\text { surface }\end{array}$ \\
\hline Compound 1 & -4.64 & 3.96 & -5.63 & -0.03 & -5.63 & 510.003 \\
\hline Compound 2 & -3.81 & 2.06 & -5.02 & -0.00 & -5.05 & 472.084 \\
\hline
\end{tabular}

\subsection{Chemical structure of the inhibitors and corrosion inhibition}

Inhibition of the corrosion of $\mathrm{C}$-steel in $2 \mathrm{M} \mathrm{HCl}$ solution by some thiosemicarbazide derivatives is determined by potentiodynamic anodic polarization measurements, electrochemical impedance spectroscopy (EIS) and electrochemical frequency modulation method (EFM) studies. It was found that the inhibition efficiency depends on concentration, nature of metal, the mode of adsorption of the inhibitors and surface conditions.

The observed corrosion data in presence of these inhibitors, namely:

i) The decrease of corrosion rate and corrosion current with increase in concentration of the inhibitor.

ii) The shift in Tafel lines to higher potential regions.

iii) The inhibition efficiency depends on the number of adsorption active centers in the molecule and their charge density.

It was concluded that the mode of adsorption depends on the affinity of the metal towards the $\pi$-electron clouds of the ring system. Metals such as Fe, which have a greater affinity towards aromatic moieties, were found to adsorb benzene rings in a flat orientation. The order of decreasing the percentage inhibition efficiency of the investigated inhibitors in the corrosive solution was as follow: 4-phenyl-thiosemicarbazide > 4-allylthiosemicarbazide .

4-Phenyl-thiosemicarbazide exhibits excellent inhibition power due to its larger molecular size that may facilitate better surface coverage. 4-Allyl-thiosemicarbazide comes after 4-phenyl-thiosemicarbazide in inhibition efficiency due to it has lesser molecular size.

\section{CONCLUSION}

1-The study proves that thiosemicarbazide derivatives have a good ability to inhibit the corrosion of $\mathrm{C}$ - steel in $2 \mathrm{M} \mathrm{HCl}$.

2-Results obtained from DC polarization, and AC impedance methods are reasonably in fair agreement and confirmed that the inhibitor efficiency increases with increasing inhibitor concentration.

3- The results of EIS revealed that an increase in the charge transfer resistance and a decrease in double layer capacitances when the inhibitor is added and hence an increase in \% IE. This is attributed to increase of the thickness of the electrical double layer.

4- Through B3LYP/6-31G* quantum chemical calculations a correlation between parameters related to structure of some thiosemicarbazide derivatives and their ability to inhibit the corrosion process could be established.

5- The inhibition efficiency of thiosemicarbazide derivatives obtained experimentally increase with the increased in $\mathrm{E}_{\mathrm{HOMO}}$, and decreased in $\mathrm{E}_{\mathrm{LUMO}}$ and decreased in the energy of the gap $(\Delta \mathrm{E})$. 4-Phenyl-thiosemicarbazide has the higher inhibition efficiency because it had the highest HOMO energy and low $(\Delta \mathrm{E})$ values, and it was most capable of offering electrons. 4-Allyl-thiosemicarbazide has the lower $\mathrm{E}_{\mathrm{HOMO}}$ value, also the lower inhibition efficiency. 
6- The order of inhibition efficiency is 4-phenyl-thiosemicarbazide > 4-allylthiosemicarbazide.

7- The heteroatoms $\mathrm{N}$ and $\mathrm{S}$ are the active sites of the thiosemicarbazide derivatives. It can adsorb on Fe surface firmly by donating electrons to Fe atoms and accepting electrons from $3 \mathrm{~d}$ orbital of $\mathrm{Fe}$ atoms.

8- Molecular docking and binding energy calculations of thiosemicarbazide derivatives with the receptor of 3tt8-hormone of crystal structure analysis of $\mathrm{Cu}$ Human Insulin Derivative indicated that the compounds are efficient inhibitors of receptor of 3tt8-hormone.

9-Comparison of theoretical and experimental data exhibit good correlation confirming the reliability of the methods adopted here.

\section{REFERENCES}

1. M.H. Wahdan, A.A. Hermas, M.S. Morad, Mater. Chem. Phys. 76, 111-118, 2002.

2. F. Bentiss, M. Lebrini, H. Vezin, M. Lagrenee, Mater. Chem. Phys. 87, 18-23, 2004.

3. X. Liu, P.C. Okafor, Y.G. Zheng, Corros. Sci. 51, 744-751, 2009.

4. A. Al Maofari, G. Ezznaydy, Y. Idouli, F. Guedira, S. Zaydoun, N. Labjar and S. El Hajjaji, J. Mater. Environ. Sci. 5, 2081- 2085, 2014.

5. K. Barouni, A. Kassale, A. Albourine, O. Jbara, B. Hammouti, L. Bazzi, J. Mater. Environ. Sci. 5, 456-463, 2014.

6. A.S. Fouda, K. Shalabi, H. Elmogazy, J. Mater. Environ. Sci. 5, 1691-1702, 2014.

7. A. Ostovari, S.M. Hoseinieh, M. Peikari, S.R. Shadizadeh, S.J. Hashemi, Corros. Sci. 51, 1935-1949, 2009.

8. M.J. Bahrami, S.M.A. Hosseinia, P. Pilvar, Corros. Sci. 52, 2793-2803, 2010.

9. M.M. Solomon, S.A. Umoren, I.I. Udosoro, A.P. Udoh, Corros. Sci. 52, 1317-1325, 2010.

10. H.L. Wang, R.B. Liu, J. Xin, Corros. Sci. 46, 2455-2466, 2004.

11. R. Solmaz, G. Kardas, B. Yazici, M. Erbil, Prot. Met. 41, 581-585, 2005.

12. K.C. Emregul, R. Kurtaran, O. Atakol, Corros. Sci. 45, 2803-2817, 2003.

13. D. Chebabe, Z.A. Chikh, N. Hajjaji, A. Srhiri, F. Zucchi, Corros. Sci. 45, 309-320, 2003.

14. F.G. Liu, M. Du, J. Zhang, M. Qiu, Corros. Sci. 51, 102-109, 2009.

15. A.Y. Musa, A.A.H. Kadhum, A.B. Mohamad, M.S. Takriff, Corros. Sci. 52, 3331-3340, 2010.

16. K.F. Khaled, M.A. Amin, Corros. Sci. 51, 1964-1975, 2009.

17. P. Kumar, A. N. Shetty, Res. Chem. Intermed. 41, 7095-7102, 2015.

18. H. B. Ouici, O. Benali, A. Guendouzi, Res. Chem. Intermed. 42, 7085-7096, 2016.

19. K. F. Al-Azawi, S. B. Al-Baghdadi, A. Z. Mohamed, Chem. Cent. J. 10, 23-4, 2016.

20. M. Yadav, D. Behera, U. Sharma, Arab. J. Chem. 9, 1487-1495, 2016.

21. P.C. Okafor, X. Liu, Y.G. Zheng, Corros. Sci. 51, 761-768, 2009.

22. J. Zhang, J.X. Liu, W.Z. Yu, Y.G. Yan, L. You, L.F. Liu, Corros. Sci. 52, 2059-2065, 2010.

23. G. Gece, Corros. Sci. 50, 2981-2984, 2008.

24. A. M. Eldesoky, S. G. Nozha, Chinese. J. Chemical. Engineering .25, 1256-1265, 2017.

25. M. A. Diab, A. Z. El-sonbati, A. F. Sohair, A. M. Eldesoky, N. M. El-Far, J. Mol. Struct.1141,710-739, 2017.

26. A. M. Eldesoky, M. A. Diab, A. Z. El-sonbati, S. F. Salam, Int. J. Electrochem. Sci. 12, 4215-4237, 2017.

27. G. Bereket, C. Ogretir, and A. Yurt, J. Mol. Struct. (THEOCHEM). 577, 1139-1145, 2001.

28. G. Bereket, C. Ogretir, and E. Hur, J. Mol. Struct. (THEOCHEM). 578, 79-84, 2002.

29. F. Kandemirli, S. Sagdinc, Corros. Sci. 49, 2118-2130, 2007. 
30. E. F. Da Silva, M. M. Canto-Cavalheiro, V. R. Braz, J. Med. Chem. 37, 979-986, 2002.

31. K. A. Jensen, U. Anthoni, B. Kagi, C. Larsen, C. Th. Pedersen, Acta Chem. Scand., 22, 1$50,1968$.

32. Z. Bikadi, E. Hazai, J. Chem. Inf. 11, 1-15, 2009.

33. T. A. Halgren, J. Computat. Chem. 17, 490-519, 1998.

34. G. M. Morris, D.S. Goodsell, J. Comput. Chem. 19, 1639-1662, 1998.

35. M. A. Al-Khaldi, K.Y. Al-qahtani, J. Mater. Environ. Sci. 4, 593-600, 2013.

36. J. W. Schltze, K. Wippermann, Electrochim. Acta 32, 823-831, 1987.

37. D. C. Silverman, J. E. Carrico, Corrosion 44, 280- 287, 1988.

38. D. D. Macdonald, M. C. H. Mckubre, "Impedance measurements in electrochemical systems" Modern Aspects of Electrochemistry, J. O’M. Bockris, B. E. Conway, R. E. White, Eds., Plenum Press, New York .14, 61-150, 1982.

39. F. Mansfeld, Corrosion 36, 301-307, 1981.

40. C. Gabrielli, "Identification of Electrochemical processes by Frequency Response Analysis" Solarton Instrumentation Group, 1980.

41. M. El Achouri, S. Kertit, H. M. Gouttaya, B. Nciri, Y. Bensouda, L. Perez, M. R. Infante, K. Elkacemi, Prog. Org. Coat. 43, 267-273, 2001.

42. A. Anejjar, A. Zarrouk, R. Salghi, H. Zarrok, D. Ben Hmamou, B. Hammouti, B. Elmahi, S. S. Al-Deyab, J. Mater. Environ. Sci. 4, 583-592, 2013.

43. S. F. Mertens, C. Xhoffer, B.C. Decooman, E. Temmerman, Corrosion 53, 381-388, 1997.

44. G. Trabanelli, C. Montecelli, V. Grassi, A. Frignani, J. Cem. Concr. Res. 35, 1804-1813, 2005.

45. A. J. Trowsdate, B. Noble, S.J. Haris, I. S. R. Gibbins, G.E. Thomson, G. C. Wood, Corros. Sci. 38, 177-191, 1996.

46. F. m. Reis, H. G. de Melo, I. Costa, J. Electrochem. Acta 51, 1780-1788, 2006.

47. M. Lagrenée, B. Mernari, M. Bouanis, M. Traisnel, F. Bentiss, Corros. Sci. 44, 573-588, 2002.

48. E. McCafferty, N. Hackerman, J. Electrochem. Soc.119, 999-1009, 1972.

49. H. Ma, S. Chen, L. Niu, S. Zhao, S. Li, D. Li, J. Appl. Electrochem. 32, 65-72, 2002.

50. E. Kuş, F. Mansfeld, Corros. Sci. 48, 965-979 (2006).

51. G. A. Caigman, S. K. Metcalf, E. M. Holt, J. Chem. Cryst. 30, 415-422, 2000.

52. I. H. Ali, Int. J. Electrochem. Sci., 11, 2130-2141, 2016.

53. F. Samie, J. Tidblad, V. Kucera, C. Leygraf, Atmospheric Environ. 39, 7362-7373, 2005.

54. M. Karelson, V.S. Lobanov, Chem. Rev. 96, 1027-1044, 1996.

55. K. K.Taha, Ph. D thesis, Corrosion Inhibition of Brass in perchloric acid, Banglore University, 2002.

56. W. Cherry, N. fpiotis, W. Thatcher, Acc. Chem. Res. 16, 167-173, 1977.

57. R. A. Prabhu, T. V. Venkatesha, A. V. Shanbhag, G. M. Kulkarni, R. G. Kalkhambkar, Corros. Sci. 50, 33-56, 2008.

58. G. Moretti, G. Quartanone, A. Tassan, A. Zingales, Wekst. Korros. 45, 641-647, 1994.

59. A. Z. El-Sonbati, G. G. Mohamed, A. A. El-Bindary, W. M. I. Hassan, M. A. Diab, Sh. M. Morgan, A. K. Elkholy, J. Mol. Liq. 212, 487-502, 2015.

60. M. A. Diab, A. Z. El-Sonbati, A. A. El-Bindary, Sh. M. Morgan, M. K. Abd El-Kader, J. Mol. Liq. 218, 571-585, 2016.

61. A. A. El-Bindary, G. G. Mohamed, A. Z. El-Sonbati, M. A. Diab, W. M. I. Hassan, Sh. M. Morgan, A. K. Elkholy, J. Mol. Liq. 218, 138-149, 2016. 